\title{
Education for Peace in Diversified Groups: Opportunities and Threats
}

\begin{abstract}
Beata Jachimczak, Education for Peace in Diversified Groups: Opportunities and Threats. Interdisciplinary Contexts of Special Pedagogy, no. 27, Poznań 2019. Pp. 13-27. Adam Mickiewicz University Press. ISSN 2300-391X. e-ISSN 2658-283X. DOI: https://doi.org/10.14746/ikps.2019.27.01

The text addresses the problem of social changes related to the interpenetration of people with different cultures, religions, skills or nationalities in a common space, which also means that education is becoming more and more diverse in educational institutions. The transition from homogeneous groups to diverse groups in education has been and continues to be difficult due to many social, organizational and financial barriers. The analysis presented here relate to education for peace as a significant focus on a school (group) open to any individual difference as a resource for understanding oneself and the Other.
\end{abstract}

KEY WORDS: diverse groups, inclusive education, education for peace

Social changes related to the presence of persons of different cultures, religions, abilities or nationalities in the common space have also resulted in increased diversity in educational facilities. As noted by Tomasz Szkudlarek, "the notion of diversity has become one of the basic categories in social sciences in the final decades of the $20^{\text {th }}$ century, which was an element of a vision of collapse of the modernist social order. It was said about post-modernism that it was a culture for "celebrating diversity". At that time, it was a liber- 
ating concept, opening social space onto thinking in the categories of equality of various forms of individual and social life" (2015, p. 54). Such thinking about diversity has resulted in emancipation movements in the environment of people hitherto isolated or even excluded and has contributed to their fuller participation in the open environment (also the school environment). Beginnings of thinking about joint education appeared in parallel in several countries. In Europe, it is assumed that this was the moment of publication of Mary Warnock's report in 1978 (Fairbairn, Fairbairn, 2000), which performed advisory functions with respect to the integration of children with special educational needs. In the United States, movement for the sake of inclusive education was initiated more or less at the same time, according to Margaret A. Winzer (PodgórskaJachnik, 2010, p. 47). In Poland, the idea of education for all started to be implemented in the 1990s via introduction of integrated education to schools and kindergartens, as well as inclusive education (by allowing the parents to choose the educational facility, irrespective of the diagnosed disability of the child). The shift from homogeneous groups to diversified groups in education has been difficult due to numerous social, organisational and financial barriers. However, the "post-modernist redefinition of difference, which was expressed in debates about multiculturalism, disability, political and religious tolerance, sexuality or - eventually - individuality and about uniqueness of every life and rights to determine individual and group identity" (Szkudlarek, 2015, p. 54) has made the inclusive discourse dominant in the pedagogical practice and theory in the recent years.

Many authors tackle the issue of definition of inclusive education in reference to various ranges of inter-dependence, permeation or supplementation of special and general education (e.g. Booth, Ainscow, 2002, Szumski, 2010, Gajdzica, 2018). The second current of analyses is a broad area of multicultural or inter-cultural education (Lewowicki, 2000, Grzybowski, 2018 et. al.), which focuses on another factor diversifying people and searches for optimum practical solutions for joint existence in the school realm and outside of it. 
Education for all, based on recognition and understanding of diversified groups as a natural environment for development of man and building of a social community, should rely on the intersection of such various areas. Hence, remaining on the margin of multicultural or inter-cultural education, pedagogy of religion, rehabilitation, social pedagogy, pedagogy of learning difficulties, etc., yet at the same time being a special education teacher and an early education teacher, the author of this paper refers to the problem of a diversified group being aware that its diagnosis and designing educational activities is a "multi-specialisation task". However, this is the nature of school classes (partially today and definitely in the future), where the teacher is facing diversity of problems, needs, expectations in an individual and collective dimension. In spite of dedicated sub-disciplines of pedagogy which thoroughly tackle the educational theory and practice in the selected scope, it is necessary to try to analyse the comprehensive image of a diversified group in the context of space for education without violence (physical, psychical, economic, symbolic, structural, etc.) for Everyone.

The concept of diversified groups (in the school context) has not been clearly defined, yet it has been featured in the publications of the author of this paper $(2008,2015)$ and of Iwona Chrzanowska (2015) for a number of years. Both these authors, with a background in special education, understand such diversification in broader terms than just having fully able and disabled pupils in one school class. Following the system changes pertaining to the transition from segregated education to inclusive education, the author of this paper is the advocate of a broad understanding of inclusion in reference to types of school culture, discussed by Maria CzerepaniakWalczak (2018). Maria Czerepaniak-Walczak distinguishes three types of school culture:

- "elitist/ exclusive: for the beautiful, healthy and rich i.e. those who are like us;

- mass/ open/ inclusive: for the Others, including the unknown, strangers, as well as the neglected, the unhealthy and the poor; 
- closed/ occlusive: for those who - at their own choice or as a result of standards independent from them - experience isolation in a social circle which is characterised by values and patterns specific for this circle. Members of such circles do not have the possibility of leaving the enclosure" (Czerepaniak-Walczak, 2018, p. 16).

In the context of undertaken analyses pertaining to the education for peace mentioned in the title of the paper, focus on a school (group) open to any individual diversity as a resource for understanding oneself and Others is of crucial importance. In such approach, the school should be a place of possible change where, according to Tomasz Szkudlarek, "educational activities, motivated not only by the actual status, but oriented at the future and interested in change, are possible; thus, it (the activity) should be justified by the concepts that enable such change. Henry Giroux postulated... taking a look at the school not only in the context of cultures reproduced and de-legalised by it, but also as an institution of active cultural production, where hitherto non-existent meanings, different from the current ones, appear" (Szkudlarek, 2015, p. 65). A school environment, as Tomasz Szkudlarek notes (2015, p. 65), in Giroux's concept should be a place of "cultural mutations, creative re-definitions of the world, whereas meanings developed within its range should be verified via practical activities solving actual social problems - and these very problems should form a basis for the curriculum". The process of education pursued in this manner, in particular in diversified groups, could create natural conditions for reflexive induction and self-induction of young people to positive interdependence which David W. Johnson and Roger T. Johnson (2005, p. 283) considered the indispensable component of consensual peace, jointly worked out by a group.

Education for peace has been an area of interest of pedagogy for a number of years. As noted by Joanna Leek (2014, p. 248) "the term peace pedagogy was used for the first time by Pope Paul IV in 1969; in the next years, the term became popular thanks to UNESCO". In Poland, this problem was tackled by, among others, Bogdan Su- 
chodolski, Irena Wojnar and Eugenia A. Wesołowska (Leek, 2014). In reference to the UNICEF documents, Joanna Leek (p. 249) notes that "education for peace refers to the process of promoting knowledge, skills, stances and values that are necessary to effect changes in behaviour which gives children, youth and adults the possibility of preventing conflicts and violence, solving conflicts peacefully and fostering convenient conditions for peace on the inter-personal, personal and international area, as well as within individual states". The stances above, defined as the assumptions of education for peace, should be present in daily experiences of pupils who, in conflict situations, independently, or with the support of others, strive to develop relations agreed by all parties, based on respect, acceptance, understanding and free from violence.

When thinking about diversified groups in the context of education for peace, it is necessary to focus not so much on the learning outcomes reflected by school grades, results of external examinations of pupils (which translate to the designed and pursued paths of professional careers and further life plans of young people), but on the effects of building soft skills in the area of self-understanding and understanding others, as well as comprehending mechanisms of building inter-dependence and joint liability for own functioning and the functioning of the group.

In their analyses, David W. Johnson and Roger T. Johnson (2005) distinguished two types of peace: "imposed peace" and "consensual peace". By referring these two concepts to the school situation, one can notice threats and opportunities for the functioning of diversified groups, in which more conflict situations are bound to appear naturally, frequently resulting from misunderstanding, unfamiliarity with or absence of inter-personal competence of its members or low level of such competence. Threats resulting from "imposed peace" should be searched for in insufficient preparation of teachers (as well as parents) in the area of educational competence, which may be manifested in the fact that adults indicate principles of "peaceful" functioning in a group or concede that the "winner" (often physically, intellectually stronger or having advantage in 
numbers) imposes his/ her domination and indicates privileges and dependences created in a group. Such mode of conduct in a school class, according to Johnson and Johnson (2015), leads to emergence of negative dependence, which will not be conducive to individual development of every member of the group and will not be effective in induction to joint participation, shared liability respecting the diversity of every person.

On the other hand, the author of this paper notices opportunities in the possibility of using the potential of all educational entities involved in education based on diversity, permeation of cultures, religions, development possibilities and limitations of man. However, bringing together different people does not guarantee solving conflicts which may arise among them. In order to use the situation of diversity for pro-development and educational purposes, it is necessary, apart from contacts, to create a space for building interhuman relations.

One of the conditions for building correct relations is support in the teaching of soft competence, both in adults and children. Such competence "refers to personal skills, character traits, the kind of people that we are and the manner in which we perceive the environment and the mode in which we act. ... the way in which we handle tasks set before us and the way in which we solve problems that appear in our lives. Soft competence is related to psyche and social skills. It focuses on man's behaviour and man's stances in various situations" (Konieczna-Kucharska, 2015, pp. 231-232). High level of such competence in teachers and students is necessary to create conditions in a school class that would be conducive to building positive relations in a group.

David W. Johnson and Roger T. Johnson (2005, p. 285) include the following among the above-mentioned conditions:

- creation of situations aimed at cooperation assuming joint purposes (and reduction of rivalry);

- creation of situations conducive for personal and individual talks based on an honest exchange of thoughts;

- acknowledgement of equal status of every group member; 
- provision of support on the part of authorities for building contacts and relations inside the group.

The interpersonal contacts built in this manner may contribute to the reduction of prejudice and create long-term positive relations in school communities and may be transferred further, to out-ofschool situations. Eventually, they may prepare young people for understanding themselves and others and make them ready for non-violent solving of new conflict situations. In line with the author's own educational practice ${ }^{1}$, creation of space for getting to know oneself and for building relations among members of one team, as well as among cooperating class teams, offered measurable effects with respect to reduction of violence-related behaviour in the environment of an integration school. Commencement of activities in this respect required finding time in the teaching-learning process for conscious and reflectively planned project tasks for pupils in a given class, as well as for "partner" classes. The project of partner classes assumed a three-year cooperation between the first grade class starting education in a primary school and the fourth grade, which ended the cycle of early-school education with the same teacher. Joint educational projects, as well as joint out-ofschool classes allowed for building relations based on talks, learning and understanding oneself, which fostered responsibility for the Other. In line with the conducted longitudinal studies ${ }^{2}$, some of such relations established in a diversified group survived for a number of years and the acquired competence for solving difficult, conflict situations has already been used in adult life in the process of peer support (former school friends ${ }^{3}$ ) in his/ her new

1 The author worked as a teacher in integration classes in a primary school between 1993 and 2005.

2 The author conducts longitudinal studies focused on biographies of several selected pupils with respect to the planning of their education and life path (1998 - to date).

${ }^{3}$ In this case, this is the persisting peer tutoring (often with the use of new media) between a fully-able girl and a boy with autism spectrum disorder (Asperger Syndrome diagnosis) who continues education at a university. 
social environment. This is the long-term effect which results in openness to new situations and ability to find one's bearings in an acceptable and socially desired manner.

Confirmation of the above research experiences of the author is also found in the analyses of Przemysław Grzybowski and Grzegorz Idzikowski (2018, p. 69), who quote the words of a student from an integration school: "difficulties sometimes appear in communication. Fortunately, the more time we spend together, the better we understand each other. There are a lot of funny stories related to Otherness. They most often refer to misunderstanding each other... Otherness is not something that one should be afraid of. Otherness is unique. Apart from the fact that you can get to know new cultures, you can find real friendship". Teachers examined by these authors indicate difficulties too, but they also point out positive experiences of work in a diversified group, as far as relations inside the group are concerned. "Work in classes which include disabled students and students from other countries requires the teacher's great sensitivity with respect to the needs and possibilities of these students. Change in the place of residence, school, friends, new situations is very stressful for children. We are trying to minimise such stress for them and make them feel good and comfortable in our environment. Friends from the class, who are greatly involved in helping them find their bearings in a new situation, are a great support for such students. Such meetings are a wonderful lesson for everyone" (Grzybowski, Idzikowski, 2018, p. 108).

Thus, building relations seems to be one of the most important elements of work in a diversified group and requires both readiness and openness of teachers to create situations conducive to open (often difficult) dialogue and creation of a space for social integration. As indicated by David W. Johnson and Roger T. Johnson (2005), the more diversified a group (with respect to culture, ability, religion, etc.), the greater the need for conscious, planned and responsible building of a community based on acknowledgement and respect for individuality and distinctness of every man. Thus, for a diversified group to become an opportunity for education for peace 
understood as a status of social relations characterised by cooperation, understanding and respect for distinctness of all parties, preparation of both present and future teachers to work with such groups is of crucial importance.

The report of the project "Teacher Education for Inclusion" (TE4I) implemented by the European Agency for Special Needs and Inclusive Education clearly shows that education of teachers is the vital element of the system which translates to the functioning of future citizens, as well as initiates changes that are necessary for broader introduction of education of diversified groups (European Agency for Special Needs and Inclusive Education, 2012, p. 7). The agency considers the following core values the most important in the work of an "inclusive" teacher related to the process of teaching/ learning:

1. valuing learner diversity: difference is considered a resource and an asset to education;

2. supporting all learners: teachers have high expectations for all learners' achievements;

3. working with others: collaboration and teamwork are essential approaches for all teachers;

4. personal professional development: teaching is a learning activity; teachers take responsibility for their lifelong learning (p. 13).

Teachers trained in this manner should be ready to perform the teaching process based on multiple interactions of the child's traits and the traits of the educational facility (Brzezińska, 2002). The school's openness and readiness to look for areas for "interaction" of individual participants of the didactic and educational processes may provide an opportunity for education for peace, introducing respect for other people and handling conflict situations. It is necessary to foster such social situations in which every student, irrespective of his/ her individual needs, may effectively and fully perform various social roles, but not only. On the other hand, a school "closed" to diversity may condition emergence of difficult situations from the point of view of correct functioning of individual 
students within a team, as well as among whole teams. The most frequent "sins" committed in educational facilities and related to low efficiency of work in a diversified group include: excessive focus on didactic activities in relation to the necessity of satisfying "ranking" expectations; neglecting the educational process; insufficient care for interpersonal relations in a group and at school; lack of respect for different values, needs and possibilities of students.

Work in a diversified group, as noted earlier, requires the teacher to acknowledge every child's right to be educated among peers in a facility that was chosen by the child's parents. Such acknowledgement means acceptance of "responsibility by adults for activities in four important areas of pedagogical work, which make it possible to help the student build positive relations with oneself and with others. They include:

- getting to know: observation of the child during classes and outside of classes; evaluation of learning outcomes in reference to the student's starting point (internal); establishment of contacts with parents; in-depth analysis of documents pertaining to the child's health; building understanding with other teachers for the sake of fostering an environment supporting the child's school functioning;

- acceptance: permitting behaviour that results from the student's development disorders and may be accepted by others; introduction of changes in work with the student with special educational needs instead of challenging values, bases and standards;

- acquisition: building authority by taking interest in the student; focus on positive features, behaviour and skills; supply of positive feedback in individual and group context;

- change: by supporting natural activity (every child has a strong side: sport, art talents, sense of humour, organisational skills...); avoiding control and enforcement: gradual withdrawal from control activities; partnership: joint responsibility (teacher in the role of a consultant and adviser, democratic establishment of objectives, tasks to be performed, consequences 
of own decisions); individual and group contracts" (Chrzanowska, Jachimczak, 2015 p. 189).

The opportunity for building positive and long-term relations based on trust and positive dependence are cooperation-type activities which, when properly designed and implemented, may enhance positive interactions that are created in a group. David W. Johnson and Roger T. Johnson (2013, pp. 372-374) indicate three methods of work applied most frequently in a school class. The first of them is individual learning focused on the students who work independently and accomplish learning outcomes not related to objectives of other students. Another form distinguished by them is competitive learning when students work against one another, in order to accomplish a stipulated objective, which may be accomplished by one or a few of them. In competitive situations, students look for effects that are beneficial for them, but may be detrimental for all other members of the group. The last form indicated by these authors is cooperative learning. This is work in small groups relying on teamwork to maximise the effects of own work and to provide one another with reinforcement and support. As part of this form of work, students/ people look for objectives and strive for results which are beneficial both for them and for all other members of the group. However, for cooperation activities to be successful, they must be properly planned and implemented. Johnson and Johnson indicate five basic elements of every lesson that is focused on cooperation in small groups. The first and the most important element is, according to them, positive interdependence. It exists when members of the group notice and acknowledge that they are related in a manner that accomplishing individual success is possible only when everybody accomplishes it. The second important element of group learning is individual and group responsibility. The group has to be responsible for accomplishing its objectives, but also every member of the group has to be responsible and engaged, making own contribution to work. The third important element is "promotive interaction", which may be explained as interactions that support activities undertaken by students. As part of these interactions, 
members of the group share their resources, help one another, support one another, encourage one another to further work and praise one another's efforts and effects. In this respect, it is important to take care of the school support system (so that every student may receive assistance of somebody who is involved in help in learning), as well as the personal support system (every student may count on social and emotional support). The fourth necessary element is providing the students with interpersonal skills and ability to work in small groups such as, e. g., leadership, decision making, building trust, communication and conflict management. The fifth element of cooperative learning is "group processing" i.e. the ability to work in a group during the entire process, which consists of discussions pertaining to the modes of accomplishing the stipulated objectives, maintenance of positive, effective working relations, as well as conflict-free evaluation of actions of group members with respect to their utility or lack of utility and in relation to this, making decisions whether specific activities should be continued or changed.

Remodelling the school's work from individual work for the sake of cooperative work in diversified classes seems to be a justified assumption for building positive relations based on cognition, understanding and acceptance of oneself and others.

\section{Recapitulation}

Social diversity resulting from various causes, that has also reached schools as a realisation of premises of education for all in the main current of teaching (no divisions, segregation) on the one hand increased - with respect to quality and quantity - emergence of conflict situations in intra and inter-personal relations. On the other hand, it created a space for getting to know oneself and Others in difficult situations, as well as a space for building dialogue for the sake of education for peaceful co-existence of people who are diversified with respect to culture, religion, ethnic origin, ability, etc. However, in order to make use of this opportunity which appeared 
together with opening of the school to Everybody, it is necessary to combine it, in a reflexive manner, with "education for peace, which is meant to praise kindness in stances and pro-social behaviour, support respect for human dignity, accept equality among people, promote activities undertaken jointly against injustice in own community and inter-human relations, liability of every human being for maintenance of peace" (Leek, 2014, pp. 255-256).

For the emergence of diversified groups to be a chance for enhancing positive relations and dependences of people not only in the educational context, but also as a long-term mode of building social relations, externalised belief about their rank and significance in the life of every man is necessary. However, skills in the area of support granted to every child and support granted to adult participants of educational process are also necessary. Thence, preparation of all employees of a pre-school/ school is necessary, as well as adult legal guardians of the child within the scope of: recognition of equal rights of everyone to satisfy their needs; basic knowledge about the causes of difficulties in socio-emotional functioning of people and effective measures undertaken in conflict situations. Bogdan Śliwerski (2015) accurately captured the tasks of modern pedagogy referring them to the situation of post-industrial revolution; nevertheless, these challenges are also related to the issue of positive use of inclusive education for the purpose of building a community ready for transmission of behaviour free of prejudice, violence and exclusion, which are tackled by the author of this paper. Śliwerski noted that we are currently facing the "challenge of building a humanum civilisation, in which we will help not only children and youth, but the world of adults or elderly solve their daily problems in real life with simultaneous understanding of senses occurring in the virtual world. For the first time pedagogy must become not only the forerunner of social changes and build or co-create the future, but it must also defend humanity in the conditions of increasingly de-humanising world. We cannot be passive and stand on the side of manipulators, look at toxic changes and even critically describe and interpret them; we have to start to in- 
tervene, oppose what is pathological and destructive in order to reinforce the self-defence potential in next generations against the rapacity of the world that is hiding evil" (Śliwerski, 2015, p. 50).

\section{Bibliography}

[1] Booth T., Ainscow M. (2002), Index for inclusion, London.

[2] Brzezińska A. (2002), Wspótczesne ujęcie gotowości szkolnej, [in:] Brejnak W. (ed.), O pomyślny start ucznia w szkole, Warsaw.

[3] Chrzanowska I., Jachimczak B. (2015), Praca wychowawcza w grupie zróżnicowanej - uczeń ze specjalnymi potrzebami edukacyjnymi w szkole ogólnodostępnej, [in:] Pyżalski J. Wychowawcze i społeczno-kulturowe kompetencje wspótczesnych nauczycieli, Łódź.

[4] Czerepaniak-Walczak M. (2018), Kultura szkoły jako srodek $i$ ośrodek poszanowania prawa do edukacji, [in:] Gołębniak B.D., Pachowicz M. (ed.), Ku inkluzji społecznokulturowej w szkole, Poznań.

[5] European Agency for Special Needs and Inclusive Education (2012), Profile of Inclusive Education Teacher, European Agency for Special Needs and Inclusive Education Odense, Denmark.

[6] Fairbairn G., Fairbairn S. (2000), Integracja problem etyczny?, [in:] G. Fairbairn, S. Fairbairn (ed.), Integracja dzieci o specjalnych potrzebach edukacyjnych. Wybrane zagadnienia etyczne, CMPPP, Warsaw.

[7] Gajdzica Z. (2018), Czas i przestrzeń w dwóch kulturach edukacji włączającej uczniów z niepetnoprawnościami. Ruch Pedagogiczny. Numer specjalny dedykowany Profesorowi Tadeuszowi Lewowickiemu, Warsaw.

[8] Grzybowski P., Idzikowski G. (2018), Inni Obcy - ale Swoi. O edukacji międzykulturowej $i$ wspólnocie w szkole integracyjnej, Bydgoszcz.

[9] Jachimczak B. (2008), Grupy zróżnicowane - wyzwanie dla wspótczesnej edukacji, [in:] J. Balvin (ed.), Interkulturalita a národnostné menšiny: v sociálnych, filozofických, pedagogických, kultúrnych, historických a prírodovedných súvislostiach, Nitra.

[10] Johnson D.W., Johnson R.T. (2013), The Impact of Cooperative, Competitive, and Individualistic Learning Environments on Academic Achievement, [in:] J. Hattie \& E. Anderman (ed.), International Handbook of Student Achievement (372-374). New York: Routledge, <https://www.researchgate.net/publication/260596923_ Johnson_D_W_Johnson_R_T_2013_The_impact_of_cooperative_competitive_ and_individualistic_learning_environments_on_achievement_In_J_Hattie_E_An derman_Eds_International_handbook_of_student_achievement_372>. 
[11] Johnson D.W., Johnson R.T. (2005), Essential Components of Peace Education. Theory Into Practice. Peace Education, Volume 44, Number 4 (pp. 280-292), London.

[12] Konieczna-Kucharska M. (2015), Miękkie i twarde kompetencje nauczycieli, Zeszyty Naukowe Politechniki Częstochowskiej Zarządzanie No. 19(2015) pp. 229-241 available at: <http:/ / www.zim.pcz.pl/znwz>.

[13] Leek, J. (2014), Pomiędzy porozumieniem a zrozumieniem. Wyzwania edukacji na rzecz pokoju, „Studia Dydaktyczne”, No. 26.

[14] Lewowicki T. (ed.) (2000), Edukacja międzykulturowa w Polsce i na świecie, Wydawnictwo Uniwersytetu Śląskiego, Katowice.

[15] Podgórska-Jachnik D. (2010), Ruch inkluzywny a zmiana oblicza wspótczesnej edukacji. W.V. Lechta (ed.), Transdisciplinárne aspekty inkluzíonej pedagogiky, Trnava, EMITplus b.r.o., p. 47.

[16] Szkudlarek T. (2015), Różnice, równość i edukacja: polityki inkluzji i ignorancja, [in:] Komorowska-Zielony A, Szkudlarek T. (ed.), Różnice edukacja inkluzja, Gdańsk.

[17] Szumski G. (2010), Wokót edukacji włączającej. Efekty kształcenia uczniów z niepetnosprawnością intelektualna w stopniu lekkim w klasach specjalnych, integracyjnych i ogólnodostępnych, Warsaw.

[18] Śliwerski B. (2015), Pedagogika na zakręcie, [in:] Komorowska-Zielony A., Szkudlarek T. (ed.), Różnice edukacja inkluzja, Gdańsk. 